\title{
Larger Benthic Foraminifera from the Paleocene Sediments in the Chehel-Kaman Formation, North-Eastern Iran
}

\author{
Batool Rivandi ${ }^{*}$, Seyed Mohammad Ali Moosavizadeh ${ }^{2}$ \\ ${ }^{1}$ Department of Geology, Faculty of Science, Ferdowsi University of Mashhad, Mashhad, Iran \\ ${ }^{2}$ Department of Geology, Faculty of Science, Yazd University, Yazd, Iran \\ Email: ${ }^{\text {ba ri730@stu.um.ac.ir }}$
}

Received 30 January 2015; accepted 20 April 2015; published 27 April 2015

Copyright (C) 2015 by authors and Scientific Research Publishing Inc.

This work is licensed under the Creative Commons Attribution International License (CC BY). http://creativecommons.org/licenses/by/4.0/

(C) $\underset{\mathrm{EY}}{\mathrm{i}}$ Open Access

\begin{abstract}
This study is the micropaleontological investigation of the Chehel-Kaman Formation of Paleocene age from Kopet-Dagh basin, NE of Iran. Thirty three species of diagnostic benthic foraminifers belonging to genera Miscellanea, Operculina, Lockhartia, Rotalia, Akbarina, Pseudocuvillerina, Smoutina, Davisina, Idalina, Valvulina, Laffitteina, and Ranikothalia are recorded based on detailed petrographic analysis. The rocks are entirely shallow marine in rigin with biotic assemblages confirming Chehel-Kaman Limestone of the Paleocene age. The analyses of benthic foraminifers suggest that the deposition of the Paleogene sequence occurs in warm and shallow marine environments. In this paper Ranikothalia sindensis partial zone was reported in association with Miscellanea miscella, M. juliettae and M. yvettae.
\end{abstract}

\section{Keywords}

Chehel-Kaman, Kopet-Dagh, Foraminifera, Paleocene, Ranikothalia sindensis Partial Zone

\section{Introduction}

The Paleogene following the important Cretaceous-Paleocene (K-P) catastrophic extinction was a time of recovery biota and flora. Larger benthic foraminifera were major rock builders in tropical and subtropical shallow seas especially in Para-Tethys realm. They were photosymbiotic biota and lived in warm, oligotrophic, shallow waters within the photic zone. Latest Paleocene (shallow benthic zone 4) at low latitudes was dominated by larger foraminifera (Miscellanea, Ranikothalia, Assilina). Knowledge of the larger foraminifera in Middle East

${ }^{*}$ Corresponding author.

How to cite this paper: Rivandi, B. and Moosavizadeh, S.M.A. (2015) Larger Benthic Foraminifera from the Paleocene Sediments in the Chehel-Kaman Formation, North-Eastern Iran. Open Journal of Geology, 5, $224-229$.

http://dx.doi.org/10.4236/ojg.2015.54020 
has not progressed much since Henson’s monographs (1950), followed up by Sampò (1969). However, between 1973 and 1983 the National Iranian Oil Company published a series of monographs by Rahaghi on larger foraminifera from Iran. These papers enlarged the census of available taxa to a considerable extent. Here, however, only Rahaghi's works of 1983 are relevant. The aim of this work is to determine lithostratigraphic units and larger benthic foraminifera.

\section{Geological Setting}

The Kopet-Dagh is an inverted basin [1] extended from the east of the Caspian Sea to NE Iran, north Afghanistan and Turkmenistan [2] [3]. Following the closure of Palaeo-Tethys in the Middle Triassic [4] and the opening of Neo-Tethys during Early to Middle Jurassic [3], the Kopet-Dagh basin formed during Early to Middle Jurassic [5]. Relatively continuous sedimentation took place from the Jurassic through the Neogene in the KopetDagh Basin [6] [7]. This sedimentation was recorded by five major transgressive-regressive sequences [8]. Close to the end of Cretaceous period and the beginning of Paleocene epoch, the epicontinental sea regressed toward the northwest and a thick interval of the lower Paleocene redbed siliciclastic sediments were deposited in fluvial environments (Pesteligh Formation). During late Paleocene, the sea level rose rapidly with abrupt shifting of potential siliciclastic point sources toward the central and eastern parts of the basin. This transgression allowed carbonates of the Chehel-Kaman Formation to be deposited [9]-[11]. Kopet-Dagh basin is very important because it hosts the giant Khangiran and Gonbadli gas fields. What's more, upper Paleocene carbonated in this basin constitutes one of the producing intervals. Chehel-Kmana Formation with the age of Paleogene is a major formation in Kopet-Dagh basin at northeastern of Iran.

\section{Material and Methods}

The present study is based on one stratigraphic section (Padeli section) in East of Kopet-Dagh basin which is well exposed (Figure 1). In the field studies 115samples were collected (164 thin sections) to determine associated larger benthic foraminifera in cemented carbonate rocks. Thin sections were stained by Alizarin red S [12] and were studied using standard petrographic microscope techniques.

\section{Lithostratigraphy}

Chehel-Kaman Formation (Paleogene) in the Kopet-Dagh basin is mainly composed of limestone, dolomite and interbeds of marl, shale and evaporite sediments. It conformably overlies the siliclastic sediments of Pestehligh and underlies the olive shale of Khangiran Formations. As a result of the litostratigraphic study of the ChehelKaman Formation, it is divided into 5 units in Paddeli section. In Paddeli section, unit 1 (40 meters) encompasses the alternation of yellow limestone, shale, thin green marl and gypsum. Unit 2 also is 40 meters thick, containing 24 meters of gray shale with gastropods. Unit 3 is composed of sandy limestone and conglomerate. Unit 4 has maximum thickness in this section (70 meters). This unit consists of dark gray with very thin bedded of limestone. This unit has two shell beds. The last unit is 28 meters thick and is composed of limestone, sandy limestone and dolomite, in which one paleosol is observed, confirming water withdrawal.

\section{Biostratigraphy}

The following twenty eight genera taxa were identified in the studied section (some figure is in Plate 1): Akbarina primitive, Biloculina sp., Coskinonrajkae, Cuvillierina sireli, Cribrobulimina carniolica, Davisina sp., Elazigella altineri, Elphidium sp., Kathina sp., Kathina selveri, Kayseriella decastroi, Idalina sinjarica, Laffitteina khorasanica, Lockharthia conditi, Lockhartia haimei, Micsellanea globularis, Miscellanea sp., Miscellanea minutes, Miscellanea miscella, Miscellanea iranicus, Miscellanea yvettae, Mississippinidae indent, Operculina sp., Operculina salsa, Ornotononion moorkensii, Ornatorotalia granum, Planorbulinaaff cretae, Pseudocuvillerinasireli, Rotalia sp., Ranikothalia nuttalli, Ranikothalia sindensis, Rotalia indent, Rotalia trochidiformis, Sakeasaria sp., Smoutina sp., Strosellahaasteri, Valvulinasp. The SBZ1-SBZ2 phase is represented in the Kopet-Dagh basin by only a few genera of smaller rotaliids (Rotalia and Laffitteina) and miliolids (Idalina). Laffitteina species are well-known foraminifera in Middle Paleocene to Late Paleocene units. 

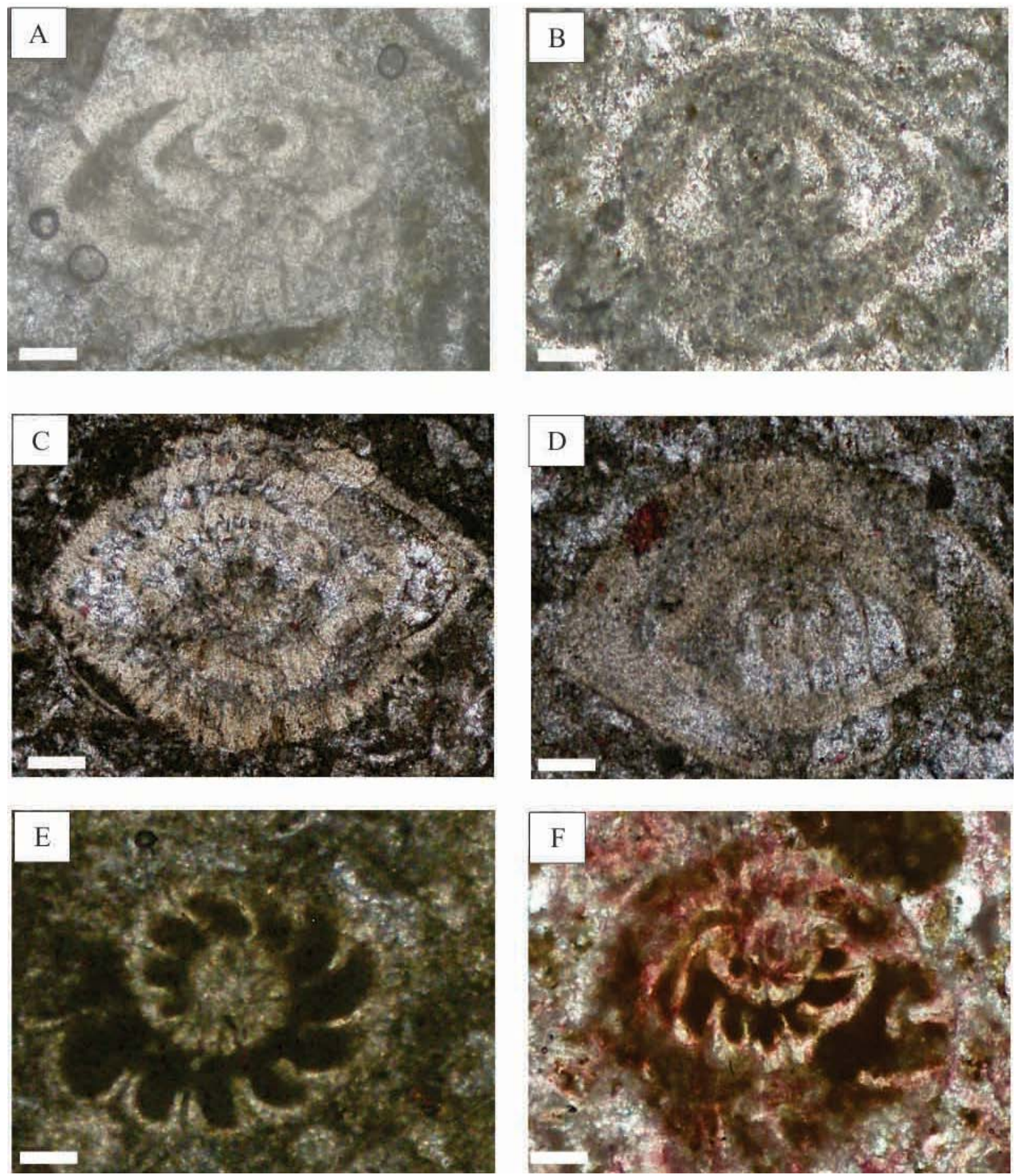

Plate 1. (A) Lockhartiaconditi (Smout, 1954), axial section, sample No. 35; (B)-(C) Miscelleinamiscella (d’Archiac \& Haime, 1853), axial section, sample No. 53; (D) Miscelllanea sp., axial section, sample No. 80; (E) Miscellanites minutus (Rahaghi, 1983), axial section, sample No. 32; (F) Miscellanea juliettae (Leppig, 1988), axial section, sample No. 42.

The SBZ3-SBZ4 interval in the Kopet-Dagh basin commenced with the appearance of many new taxonomic lineages including genera of rotaliids (Lockhartia and Kathina), miliolids (Triloculina and Quinqueloculina), pellatispirids (Miscellanea), nummulitids (Ranikothalia and Operculina), and lepidorbitoids (Daviesina). The latest Paleocene (Biozone SBZ4) miscellanids and ranikothalids are replaced by Early Eocene alveolinids and nummulitids, which come to dominate LBF assemblages in the western Tethyan realm at the P-E boundary (e.g. 


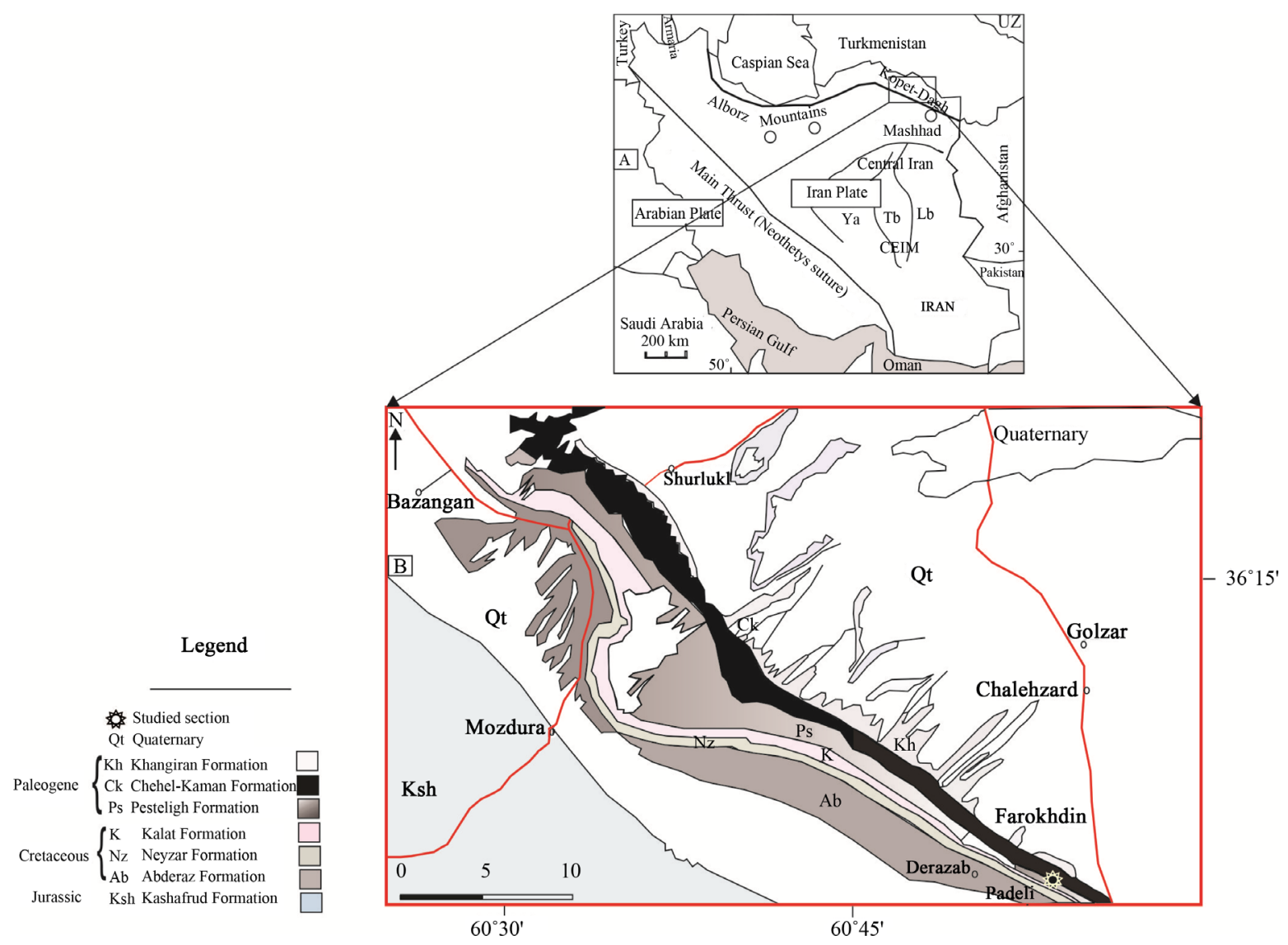

Figure 1. (A) Structural geology and geography map of Iran showing the main sutures, structural units and geographic areas (redrawn from Ghasemi-Nejad et al., 2012). UZ: Uzbekistan; Yb: Yazd Block; Tb: Tabas Block; Lb: Lut Block; CEIM: Central-East Iranian Microcontinent. (B) Location map of the Chehel-Kaman Formation at Padeli section.

Scheibner et al. 2005; Scheibner \& Speijer 2008), the so-called larger foraminifer-turnover (LFT, Orue-Etxebarria et al. 2001). But there aren’t any genera of Alveolinids and Nummulites.

Based on the aforementioned benthic foraminiferal species; identified in the studied section and compared to those identified in other countries, especially the biozonation of larger foraminifera of the Tethyan Paleocene and Eocene recorded by Serra-Kiel et al. (1998), we assigned Late Paleocene (Selandian-Thanetian) age to the Chehel-Kaman Formation in the studied area (Figure 2). The stratigraphic distribution of Ranikothalia sindensis demonstrates that a Ranikothalia sindensis partial zone can be established for the Upper Paleocene (Thanetian). Presence of species such as Coskinonrajkae, Elazigella altineri, Lockhartiadiversa, Miscellanea yvettae, Ranikothalia nuttalli, Cribrobulimina carniolica, Idalina sinjarica represents the age of Thanetian according SBZ3 zone; and some forms like Akbarina primitiva, Pseudocuvillerina sireli, Haymanella elongata, Miscellanea sp. show Selandian age (SBZ2).

\section{Conclusion}

Five lithological units with variable thickness have been recognized in the studied section from Kopet-Dagh basin in northeast of Iran. 27 taxa of shallow benthic foraminifera, which belong to five families, have been identified from Early Paleogene sediments. Ranikothalia sindensis partial-range zone is appropriate for larger foraminiferal zonation of the Late Paleocene (Thaneian) in this basin. The Selandian-Thanetian age has been assigned to the Chehel-Kaman Formation in the studied area.

\section{Acknowledgements}

We are grateful to Ferdowsi University of Mashhad for the financial supports of this research. We would also 


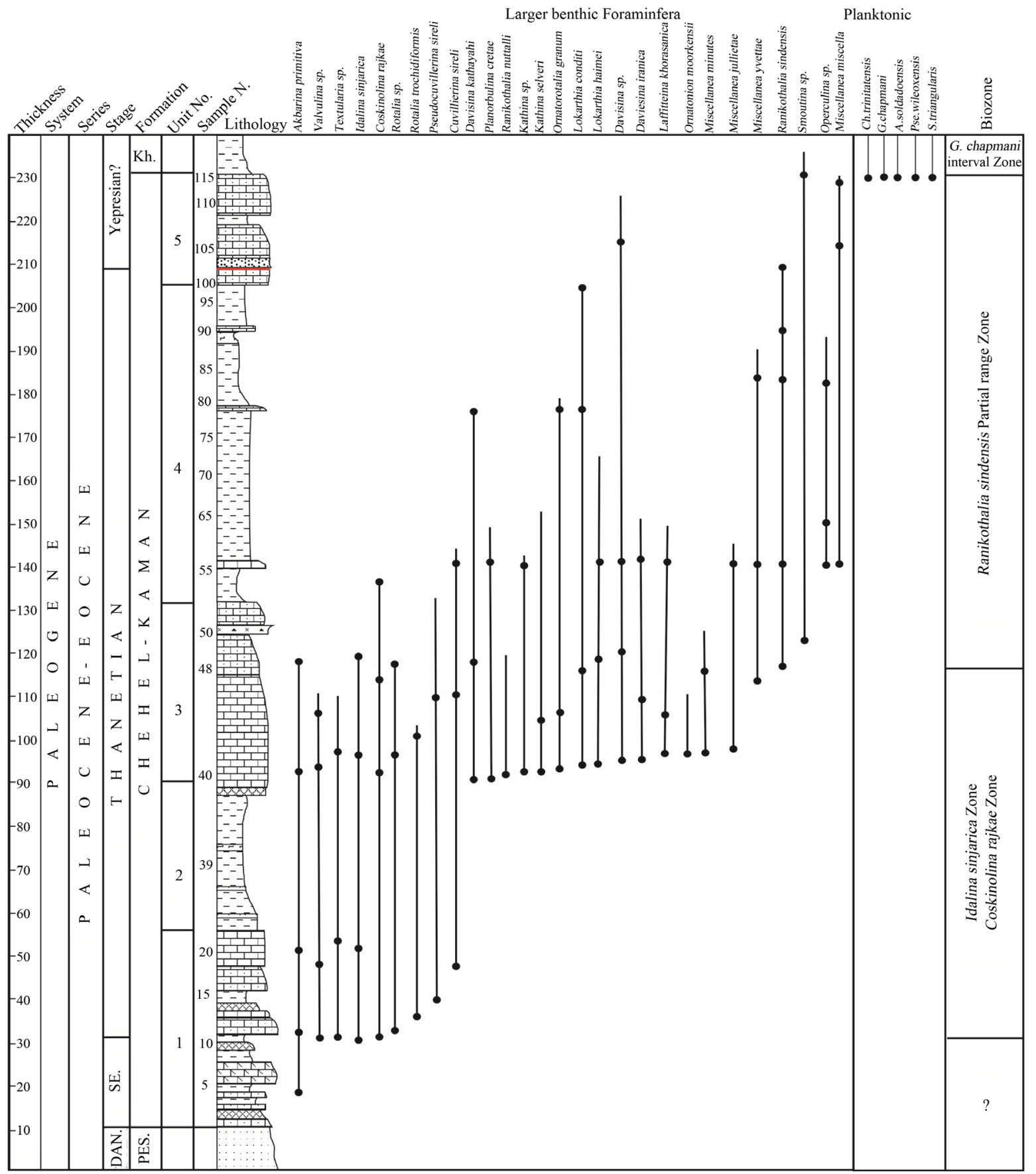

Figure 2. Stratigraphy column of Chehel-Kaman formation in paddeli section.

like to thank Professor Eustoquio Molina from Zaragoza University. Also we thank Dr. J. Zamagni (Postdam University), Dr. J. Bowen Powel (Miami, Florida), Dr. A. Govindan, and Dr. M. Boukhary.

\section{References}

[1] Allen, M.B., Vincent, S.J., Alsop, G.I., Ismail-Zadeh, A. and Fleckerd, R. (2003) Late Cenozoic Deformation in the South Caspian Region: Effects of a Rigid Basement Block within a Collision Zone. Tectonophysics, 366, 223-239. http://dx.doi.org/10.1016/S0040-1951(03)00098-2

[2] Afshar-Harb, A. (1979) The Stratigraphy Tectonics and Petroleum Geology of the Kopet-Dagh Region, Northeast Iran. 
Ph.D Thesis, University of London, London, 316.

[3] Buryakovsky, L.A., Chilinger, G.V. and Aminzadeh, F. (2001) Petroleum Geology of the South Caspian Basin. Gulf Professional Publishing, Houston, 442 p.

[4] Alavi, M. (1997) Tectonostratigraphy Synthesis and Structural Style of the Alborz Mountain System in Northern Iran. Journal of Geodynamics, 21, 1-33. http://dx.doi.org/10.1016/0264-3707(95)00009-7

[5] Garzanti, E. and Gaetani, M. (2002) Unroofing History of Late Paleozoic Magmatic Arcs within the "Turan Plate” (Tuarkyr, Turkmenistan). Sedimentary Geology, 151, 67-87. http://dx.doi.org/10.1016/S0037-0738(01)00231-7

[6] Kalantari, A. (1987) Biofacies Relationship of the Kopet-Dagh Region: Tehran, National Iranian Oil Company Exploration and Production Group, Tehran, 1 Sheet.

[7] Mahboubi, A., Moussavi-Harami, R., Lasemi, Y. and Brenner, R.L. (2001) Sequence Stratigraphy and Sea Level History of the Upper Paleocene, Strata in the Kopet-Dagh Basin, Northeastern Iran. American Association of Petroleum Geologists Bulletin, 85, 839-859.

[8] Dickinson, J.A.D. (1966) Carbonate Identification and Genesis as Revealed by Staining. Journal of Sedimentary Petrology, 36, 491-505.

[9] Scheibner, C., Speijer, R.P. and Marzouk, A.M. (2005) Turnover of Larger Foraminiferal during the Paleocene-Eocene Thermal Maximum and Paleoclimatic Control on the Evolution of Platform Ecosystems. Geology, 33, 493-496. http://dx.doi.org/10.1130/G21237.1

[10] Scheibner, C. and Speijer, R.P. (2008) Decline of Coral Reefs during Late Paleocene to Early Eocene Global Warming. eEarth, 3, 19-26. http://dx.doi.org/10.5194/ee-3-19-2008

[11] Orue-Etxebarria, X., Pujalte, V., Bernaola, G., Apellaniz, E., Baceta, J.I., Payros, A., Nuñez-Betelu, K., Serra-Kiel, J. and Tosquella, J. (2001) Did the Late Paleocene Thermal Maximum Affect the Evolution of Larger Foraminifers? Evidence from Calcareous Plankton of the Campo Section (Pyrenees, Spain). Marine Micropaleontology, 41, 45-71. http://dx.doi.org/10.1016/S0377-8398(00)00052-9

[12] Seraa-Kiel, J., Hottinger, L., Caus, E., Drobne, K., Ferrandez, C., Jauhri, A.K., et al. (1998) Large Foraminiferal Biostratigraphy of Tethyan Paleocene and Eocene. Bulletin de la Societégéologique de France, 168, 281-299. 